\title{
Respons Insulin Like Growth Factor-I Pascalatihan Fisik Sebagai Indikator Peningkatan Densitas Tulang pada Wanita Lanjut Usia
}

\author{
Neng Tine Kartinah Almuktabar \\ Fakultas Pendidikan Olahraga dan Kesehatan \\ Universitas Pendidikan Indonesia, Bandung
}

\begin{abstract}
Abstrak
Latihan fisik merupakan salah satu upaya untuk mencegah osteoporosis pada wanita lanjut usia namun sampai saat ini indikator latihan fisik yang efektif, efisien, dan aman dalam meningkatkan densitas tulang pada wanita lanjut usia di Indonesia masih belum diketahui. Tujuan penelitian untuk mengetahui hubungan respons insulin like growth factor I (IGF-I) pascalatihan fisik, progressive resistance exercise (PRE), dan senam pencegahan osteoporosis (SPO) terhadap densitas tulang. Studi kasus eksperimen desain pretes dan postes dilakukan selama 16 minggu periode April-Juli 2005. Subjek penelitian terdiri 18 wanita lansia, usia 55-65 tahun di Puskesmas Ciwaruga Bandung yang memenuhi kriteria inklusi (usia 55-56 tahun, dan tidak mengkonsumsi obat-obatan yang berpengaruh buruk terhadap densitas tulang). Analisis statistik yang digunakan uji hubungan regresi linier berganda untuk menguji hubungan respons akut dan kronik IGF-I terhadap densitas tulang. Hasil uji regresi linier berganda respons akut dan kronik IGF-I terhadap densitas tulang pada kelompok PRE dan SPO menunjukkan titik defleksi nilai densitas tulang sebesar 0,88 dan $0,83 \mathrm{~g} / \mathrm{cm}^{2}(\mathrm{p}=0,000)$. Persamaan regresi densitas tulang pada kelompok PRE $=$ $0,229-0,0005$ respons akut $+0,00006$ respons kronik $(p<0,05)$. Persamaan regresi pada kelompok SPO menunjukan densitas tulang $=0,158-0,0002$ respons akut $+0,00009$ respons kronik $(\mathrm{p}<0,05)$. Dapat disimpulkan bahwa PRE lebih efektif dan efisien dibanding SPO. [MKB. 2010;42(2):55-61].
\end{abstract}

Kata kunci: Latihan fisik, lanjut usia, IGF-I, densitas tulang

\section{The Response of Insulin Like Growth Factor-I After Having Exercise As an Indicator for Increasing Bone Density in the Elderly Women}

\begin{abstract}
Physical exercise is an effort for preventing osteoporosis in the elderly women. However, some indicators for effective, efficient, and safe physical exercises for increasing bone density in the elderly women in Indonesia are still questioning. The main purpose of research was to identify the response's correlation of IGF-I post-exercise progressive resistance exercise (PRE) and osteoporosis prevention exercise (SPO) on bone density. The experiment with pre-test and post-test design has been done for 16 weeks on April-July 2005. The subjects of this research were 18 elderly women in Ciwaruga Health Community Center (Puskesmas) that met some inclusion criteria (55-65 years old, health, and do not consume medicines which have bad effects to bone density). The multiple regression test used as statistical analysis to identify the correlation of acute and chronic responses of IGF-I on bone density. The multiple regression analysis of acute and chronic responses of IGF-1 on bone density on PRE and SPO group showed a deflection point of bone density as much as 0.88 and $0.83 \mathrm{~g} / \mathrm{cm}^{2}(\mathrm{p}=0.000)$. The regression model of bone density on PRE group $=0.239-0.0005$ acute response +0.00006 chronic response $(p<0.05)$. The regression model on SPO: Bone density $=0.158-0.0002$ acute response +0.00009 chronic response $(p<0.05)$. Conclusion: the safe indicator for initial bone density before doing PRE and SPO exercises are $0.88 \mathrm{~g} / \mathrm{cm}^{2}$ and $0.83 \mathrm{~g} / \mathrm{cm}^{2}$ respectively. Therefore, PRE is relatively more effective and efficient than SPO because PRE has high exercise intensity that can increase bone density in short duration than SPO. [MKB. 2010;42(2):56-61].
\end{abstract}

Key words: Physical exercises, elderly, IGF-I, bone density

Korespondensi: Dr. dr. Neng Tine Kartinah Almuktabar. Fakultas Pendidikan Olah raga dan Kesehatan, Universitas Pendidikan Indonesia.Jln. Gamelan No.27 Bandung. HP 087821249363, Email:ntkalmuktabar@gmail.com 


\section{Pendahuluan}

Osteoporosis merupakan salah satu masalah besar pada lanjut usia karena dapat mengakibatkan terjadinya patah tulang spontan dan menurunkan kualitas hidup lansia. Oleh sebab itu, osteoporosis perlu dicegah, agar para lanjut usia dapat memiliki kualitas hidup yang baik. Salah satu upaya untuk pencegahan yang telah dikenal oleh masyarakat adalah latihan fisik yang teratur.

Latihan fisik yang sedang berkembang di kalangan masyarakat Indonesia adalah senam pencegahan osteoporosis (SPO) yang merupakan gabungan anatara senam aerobik dengan latihan resistensi. ${ }^{1}$ Di negara maju seperti Amerika Serikat, upaya meningkatkan densitas tulang pada lanjut usia sudah menggunakan latihan resistensi. Menurut Kisner dan Colby, ${ }^{2}$ prinsip dari latihan resistensi bebannya ditingkatkan secara progresif sesuai kemampuan masing-masing individu yang disebut progressive resistance exercise (PRE). Sedangkan di Indonesia, PRE belum populer digunakan oleh para lansia yang dikarenakan masyarakat masih beranggapan latihan resisten berbahaya serta tidak aman. Oleh sebab itu perlu diketahui suatu indikator keamanan dalam melakukan latihan fisik yang bertujuan untuk meningkatkan densitas tulang para lansia.

Berdasarkan pengalaman dan penelitian efektivitas latihan fisik terhadap peningkatan densitas tulang pada wanita lanjut usia di negara maju, masih terdapat kontroversi. Beberapa peneliti mengemukakan bahwa latihan fisik dapat meningkatkan densitas tulang lumbal dan leher femur sekitar 1 sampai $2 \%$ serta ada pula yang mengemukakan kebalikkannya. ${ }^{5-7} \mathrm{Hal}$ tersebut dikarenakan adanya perbedaan dalam intensitas dan durasi program latihan setiap penelitan. Penelitian di Indonesia mengenai efektivitas dan efisiensi latihan fisik terhadap peningkatan densitas tulang pada wanita lanjut usia masih belum diketahui. Efektivitas latihan dalam meningkatkan densitas tulang dinilai dari intensitas latihan yang diberikan. Efisiensi latihan fisik dalam meningkatkan densitas tulang dinilai dari durasi program latihan. Oleh karena itu perlu diketahui penilaian intensitas dan durasi program latihan sebagai indikator latihan yang efektif dan efisien untuk meningkatkan densitas tulang pada wanita lanjut usia. Indikator penilaian latihan yang efektif dan efisien untuk meningkatkan densitas tulang adalah melalui peran insulin like growth factor I(IGF-I).

IGF-I merupakan growth hormone dependent polypeptides yang dapat diproduksi baik secara sistemik (produksi endokrin) maupun secara lokal (produksi autokrin/parakrin). Peran IGF-1 adalah menstimulasi proliferasi sel osteoblas dan meningkatkan sintesis matriks tulang, ${ }^{8}$ sehingga membantu dalam peningkatan densitas tulang. Latihan fisik akan memberi respons terhadap peningkatan produksi IGF-I. Menurut Kartinah, respons IGF-I pascalatihan fisik berupa respons akut dan respons kronik. Respons akut dilihat dengan penilaian IGF-I sebelum latihan serta segera setelah latihan yang merupakan hasil produksi lokal (autokrin/parakrin). Respons akut tersebut berkaitan dengan intensitas latihan yang diberikan. Karena itu besarnya intensitas latihan selaras dengan pembebanan mekanik yang diterima sel mechanosensitive (osteosit serta osteoblas). Semakin besar intensitas latihan maka beban mekanik yang akan diterima oleh sel mechanosensitive semakin besar pula. Menurut Lanyon dan Erlich, ${ }^{10}$ mengungkapkan stimulus berupa beban mekanik pada sel mechanosensitive akan menghasilkan IGF-I secara lokal pada tulang (produksi autokrin).

Respons kronik merupakan hasil dari produksi sistemik (endokrin) yang dikontrol oleh growth hormone (GH). Respons kronik IGF-I berkaitan dengan peningkatan baseline $\mathrm{GH}$ darah yang membutuhkan waktu. Dengan demikian respons dari kronik IGF-I menunjukkan lamanya program latihan yang merupakan training effect. Maka diperlukan penilaian indikator latihan yang efektif dan efisien untuk meningkatkan densitas tulang dengan cara mengetahui hubungan respons akut dan kronik IGF-I pascalatihan fisik seperti SPO dan PRE terhadap peningkatan densitas tulang.

\section{Metode}

Subjek penelitian berasal dari kelompok lanjut usia di Puskesmas Ciwaruga di kabupaten Bandung periode April- Juli 2005. Subjek yang dipilih sebanyak 18 orang wanita lanjut usia yang memenuhi kriteria inklusi berupa usia 55-65 tahun, sehat berdasarkan anamnesis, pemeriksaan fisis, dan EKG istirahat, dan kriteria eksklusi menderita kelainan muskuloskeletal, pemakaian obat-obatan yang mempengaruhi densitas tulang 
di antaranya heparin, kortikosteroid, tiroksin; menjalani terapi penggantian hormon khususnya hormon estrogen, melakukan program latihan fisik sebelumnya, mengkonsumsi alkohol dan kopi, serta merokok.

Penelitian dilakukan melalui studi ekperimen dengan desain penelitian adalah pretest dan postest.

Subjek dibagi dalam dua kelompok perlakuan yaitu kelompok A yang diberi latihan SPO dan kelompok B yang diberi latihan PRE, kemudian dilanjutkan dengan melakukan pemeriksaan awal pada kedua kelompok yang meliputi pengukuran densitas tulang pada lumbal 2-4 dan leher femur. Pengukuran IGF-I dilakukan sebelum latihan dalam keadaan puasa dan 10 menit setelah latihan. Setelah itu dilakukan latihan selama 16 minggu dengan frekuensi 3 kali per minggu.

SPO merupakan latihan gabungan low impact aerobic dan latihan resistensi yang memiliki intensitas sedang $(50-70 \%$ dari denyut nadi maksimal/DNM). Progressive resistance exercise merupakan latihan resistensi dengan beban yang ditingkatkan secara progresif sesuai kemampuan masing-masing individu (intensitas sebesar 50\%, $75 \%$, dan $100 \%$ ) sebanyak 3 set masing-masing 10 repetisi maksimal (RM).

Pemeriksaan akhir dilakukan untuk melihat respons latihan setelah selesai program latihan selama16 minggu sama dengan pemeriksaan awal.

Densitas tulang diukur dengan densitometer dual energy X-ray absorpsiometry (Lunar DPX-L versi 1,31).

Kadar IGF-I serum diukur dengan metode ELISA menggunakan kit kuantikinin.

Uji pengaruh respons akut dan kronik IGF-I terhadap densitas tulang menggunakan analisis multipel regresi.

\section{Hasil}

Hasil analisis uji model regresi linier hubungan respons akut/kronik IGF-1 dengan densitas tulang pascalatihan PRE diperoleh nilai $F$ hitung sebesar 0,86 dengan nilai $p=0,46$ yang berarti model regresi linier tersebut tidak bermakna. Hal itu menunjukkan hubungan respons akut dan kronik IGF-I terhadap densitas tulang pada kelompok PRE bersifat nonlinier. Untuk membuktikan hal ini, dilakukan uji piecewise linear regression.
Hasil perhitungan piecewise linear regression menunjukkan bahwa respons akut dan kronik IGF-I secara bersamaan berhubungan dengan densitas tulang, terdapat kecenderungan adanya titik belok (breakpoint) pada nilai densitas tulang $0,88 \mathrm{~g} / \mathrm{cm}^{2}$. Pengelompokan densitas tulang di atas dibagi menjadi 2 persamaan regresi yaitu regresi nilai densitas tulang di atas dan di bawah titik belok. Model regresi hubungan respons akut dan respons kronik IGF 1 terhadap densitas tulang untuk kelompok di atas titik belok dinyatakan dalam persamaan:

Densitas tulang $=0,229-0,0005$ respons akut IGF-I + 0,0006 respons kronik IGF-I

Hubungan respons akut dan respons kronik IGF-1 terhadap densitas tulang di bawah titik belok dinyatakan oleh persamaan:

Densitas tulang $=-0,0005$ respons akut IGF-I + 0,0006 respons kronik IGF-I

Hasil perhitungan dari uji $\mathrm{F}$ untuk menilai kemaknaan model regresi diperoleh nilai $\mathrm{F}$ hitung 6,25 dengan nilai $p=0,04$. Hal ini menunjukkan bahwa model regresi nonlinier tersebut bermakna, sehingga dapat disimpulkan bahwa besarnya hubungan respons akut dan kronik IGF-I terhadap densitas tulang pascalatihan PRE tergantung dari tinggi rendahnya densitas tulang pada breakpoint $0,88 \mathrm{~g} / \mathrm{cm}^{2}$. Besarnya kontribusi respons akut dan kronik IGF-I terhadap peningkatan densitas tulang diuji dengan menggunakan perhitungan $\mathrm{R}^{2}$ atau koefisien determinasi, dan didapatkan nilai koefisien determinasi $\left(\mathrm{R}^{2}\right)$ sebesar $75,2 \%$, berarti secara bersamaan besarnya kontribusi respons akut dan kronik IGF-I terhadap peningkatan densitas tulang pascalatihan PRE sebesar 75,2\%.

Hubungan respons akut dan kronik IGF-I terhadap densitas tulang pascalatihan SPO

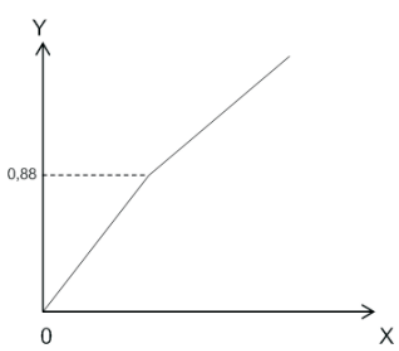

Gambar 1 Model Regresi Hubungan Respons Akut dan Kronik IGF-I Terhadap Densitas Tulang Pascalatihan PRE Keterangan:

X: Respons akut dan kronik IGF-I Y: Densitas tulang 
menunjukkan kemaknaan model regresi linier (uji F) yang terbukti tidak bermakna (F hit 3,67; $\mathrm{p}=$ $0,18)$. Hal ini menunjukkan hubungan respons akut dan kronik IGF-I terhadap densitas tulang pascalatihan SPO bersifat nonlinier. Hasil perhitungan dari piecewise linear regresion menunjukkan bahwa respons akut dan kronik IGF-I secara bersamaan berhubungan dengan densitas tulang, terdapat kecenderungan titik belok (break-point) pada nilai densitas tulang 0,83 $\mathrm{g} / \mathrm{cm}^{2}$. Model regresi hubungan respons akut dan respons kronik IGF-1 terhadap densitas tulang untuk kelompok densitas tulang di atas titik belok dinya-takan oleh persamaan:

Densitas tulang $=0,158-0,0002$ respons akut IGF-I + 0,0009 respons kronik IGF-I

Hubungan respons akut dan respons kronik IGF-1 terhadap densitas tulang untuk kelompok densitas tulang di bawah titik belok dinyatakan oleh persamaan:

Densitas tulang $=-0,0002$ respons akut IGF-I + 0,0009 respons kronik IGF-I

Hasil uji keberartian model adalah bermakna (F hit 6,$75 ; p=0,03$ ). Hal ini menunjukkan bahwa besarnya hubungan respons akut dan kronik IGF-I dengan densitas tulang tergantung pada tinggi rendahnya densitas tulang pada breakpoint $0,83 \mathrm{~g} / \mathrm{cm}^{2}$. Besaran kontribusi respons akut dan kronik pascalatihan SPO sebesar 70,8\% $\left(\mathrm{R}^{2}=\right.$ $70,8)$.

Uji keberartian respons akut IGF-I dan

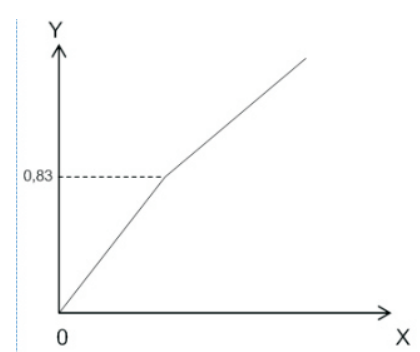

Gambar 2 Model Regresi Hubungan Respons Akut dan Kronik IGF-I Terhadap Densitas Tulang Pascalatihan SPO Keterangan:

X: Respons akut dan kronik IGF-I

Y: Densitas tulang respons kronik IGF-I secara parsial pascalatihan dilakukan dengan cara menggabungkan nilai kelompok SPO dan PRE. Hasil pengujian model regresi linier adalah tidak bermakna (F hit 0,$51 ; \mathrm{p}=$ 0,61 ) yang berarti model regrasi linier hubungan respons akut dan respons kronik IGF-I dengan densitas tulang adalah tidak bermakna. Hasil perhitungan piecewise linear regression menunjukkan bahwa respons akut dan kronik IGF-I secara bersamaan berhubungan dengan densitas tulang, dengan kecenderungan adanya titik belok (breakpoint) pada nilai densitas tulang sebesar $0,86 \mathrm{~g} / \mathrm{cm}^{2}$. Model regresi hubungan respons akut dan respons kronik IGF 1 dengan densitas tulang untuk kelompok densitas di atas titik belok dinyatakan oleh persamaan:

Densitas tulang $=0,234+0,0004$ respons akut IGF-I - 0,00001 respons kronik IGF-I

Hubungan respons akut dan respons kronik IGF 1 terhadap densitas tulang untuk kelompok densitas tulang di bawah titik belok dinyatakan oleh persamaan:

Densitas tulang $=0,0004$ respons akut IGF-I 0,00001 respons kronik IGF-I

Hasil uji model tersebut diperoleh nilai $\mathrm{F}$ hitung sebesar 19,66 dengan nilai $p=0,000$. Hal ini menunjukkan bahwa model regresi nonlinier tersebut sangat bermakna. Keberartian respons akut IGF-I dan respons kronik IGF-I secara parsial dalam model regresi tersebut dilakukan dengan uji koefisien regresi (Tabel).

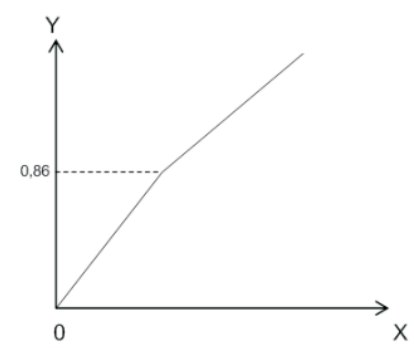

Gambar 3 Model Regresi Pengaruh Respons Akut dan Kronik IGF-I Terhadap Densitas Tulang

Keterangan:

X: Respons akut dan kronik IGF-I

Y: Densitas tulang

Tabel Uji Koefisien Regresi

\begin{tabular}{lcclc}
\hline \multicolumn{1}{c}{ Variabel } & Koefisien regresi & T Hitung & nilai $\mathbf{p}$ & Keterangan \\
\hline Respons akut IGF-I & 0,004 & 2,25 & 0,041 & $*$ \\
Respons kronik IGF-I & $-0,00001$ & $-0,61$ & 0,55 & $\mathrm{~ns}$ \\
\hline
\end{tabular}


Berdasarkan tabel uji koefisien regresi, tampak bahwa variabel respons akut secara parsial bersifat bermakna, sedangkan variabel respons kronik secara parsial bersifat tidak bermakna. Dengan demikian dapat disimpulkan bahwa yang memberi kontribusi berarti pada densitas tulang hanyalah respons akut IGF-I.

\section{Pembahasan}

Perbedaan model regresi pada kelompok PRE dan SPO terletak pada nilai titik belok, konstanta, koefisien respons akut IGF-I, serta koefisien respons kronik IGF-I. Perbedaan nilai titik belok densitas tulang akan dijelaskan sebagai berikut ini. Kelompok PRE memiliki titik belok densitas tulang sebesar $0,88 \mathrm{~g} / \mathrm{cm}^{2}$, sedangkan kelompok SPO sebesar $0,83 \mathrm{~g} / \mathrm{cm}^{2}$. Titik belok tersebut dapat diartikan sebagai nilai base line densitas tulang untuk melakukan latihan PRE dan SPO yang aman. Dengan demikian, nilai densitas tulang yang aman untuk melakukan latihan PRE dan SPO adalah sebesar $0,88 \mathrm{~g} / \mathrm{cm}^{2}$ dan $0,83 \mathrm{~g} / \mathrm{cm}^{2}$.

Perbedaan nilai konstanta pada model regresi pada kelompok PRE dan SPO sebesar 0,0229 dan 0,158 . Nilai konstanta diartikan sebagai besarnya nilai densitas tulang awal yang memberi kontribusi pada hubungan respons akut dan kronik IGF-I dengan peningkatan densitas tulang. Nilai konstanta kelompok PRE lebih tinggi dibanding kelompok SPO. Hal ini membuktikan bahwa latihan PRE memerlukan nilai densitas tulang awal lebih tinggi dibanding latihan SPO untuk memberi kontribusi pada hubungan respons akut dan kronik IGF-I dengan peningkatan densitas tulang.

Perbedaan nilai koefisien respons akut IGF-I pada kelompok PRE dan SPO sebesar 0,0005 dan 0,0002 . Nilai koefisien respons akut IGF-I dapat diartikan sebagai gambaran terukur respons akut IGF-I atas intensitas latihan yang telah diberikan. Intensitas latihan memberikan strain mekanik pada membran sel mechanosensitive yang akan merangsang pengeluaran fosfolipid. Selanjutnya aktivitas tersebut melepaskan asam arakidonik, merupakan prekursor bagi sintesis prostaglandin (PG)E. ${ }^{11}$ Prostaglandin akan menstimulasi IGF-I, sehingga kadar IGF-I dalam tulang meningkat.

Berdasarkan uraian tersebut diatas dapat disimpulkan bahwa semakin besar strain mekanik yang diterima oleh sel mechanosensitive, maka sema-kin besar pula produksi IGF-I lokal. Besar nilai koefisien respons akut IGF-I pada kelompok PRE lebih besar dibanding dengan kelompok SPO, yang berarti intensitas latihan pada kelompok PRE lebih tinggi.

Perbedaan pada nilai koefisien respons kronik IGF-I kelompok PRE dan SPO sebesar 0,006 dan 0,009 . Nilai koefisien respons kronik IGF-I dapat diartikan sebagai lamanya waktu latihan yang dibutuhkan dalam suatu program latihan agar berdampak pada pembentukan tulang (training effect). Respons kronik adalah hasil anabolisme IGF-I yang diproduksi secara sistemik (produksi endokrin). Produksi endokrin tersebut merupakan perangsangan $\mathrm{GH}$ yang kemudian menginduksi hati untuk memproduksi IGF-I. Perangsangan GH akan disesuaikan dengan kebutuhan IGF-I untuk proses anabolisme jaringan. ${ }^{12,13}$ Respons latihan fisik mampu meningkatkan perangsangan $\mathrm{GH}$ sehingga baseline $\mathrm{GH}$ dalam sirkulasi meningkat. Namun menurut Wideman dkk., ${ }^{14}$ respons latihan fisik terhadap baseline GH tidak dapat langsung meningkat tetapi akan berangsur-angsur dan membutuhkan waktu. Dengan meningkatkan baseline GH dalam sirkulasi akan meningkatkan produksi IGF-I sehingga berdampak pada peningkatan densitas tulang. Nilai koefisien respons kronik IGF-I pada kelompok SPO lebih besar dibanding dengan kelompok PRE. Hal ini membuktikan bahwa program latihan SPO akan membutuhkan waktu yang lebih lama dalam meningkatkan densitas tulang dibanding pada kelompok PRE.

Berdasarkan perbedaan koefisien respons akut dan kronik pada kelompok PRE dan SPO, dapat ditarik kesimpulan bahwa program latihan PRE memiliki intensitas latihan yang tinggi sehingga membutuhkan waktu yang lebih singkat agar dapat berdampak pada peningkatan densitas tulang. Sedangkan pada SPO memiliki intensitas latihan yang lebih rendah dibanding dengan PRE, sehingga membutuhkan waktu latihan yang lebih lama agar dapat berdampak pada peningkatan densitas tulang.

Berdasarkan tabel, hasil pengujian respons akut dan kronik IGF-I secara parsial terhadap densitas tulang, membuktikan bahwa respons akut secara parsial bersifat bermakna, sedangkan variabel respons kronik secara parsial tidak bermakna. Dengan demikian dapat disimpulkan bahwa yang berhubungan langsung pada densitas tulang saat melakukan latihan fisik hanyalah 
respons akut IGF-I.

Respons akut IGF-I terhadap densitas tulang menunjukkan bahwa produksi IGF-I lokal akan memberikan kontribusi yang sangat besar terhadap pembentukan tulang, sehingga hal ini dapat menjelaskan bahwa latihan fisik harus dilakukan secara terus-menerus.

Respons kronik IGF-I bersifat tidak bermakna terhadap pembentukan tulang, karena yang diukurnya adalah nilai IGF-I bebas yang belum bekerja pada sel target. Sebagaimana diketahui, nilai baseline IGF-I dalam sirkulasi merupakan nilai IGF-I bebas tidak terikat, padahal sebagian besar dari IGF-I terikat pada sel target untuk melaksanakan perannya. Hal ini menunjukkan bahwa penilaian respons kronik IGF-I tidak menggambarkan produksi IGF-I secara total sebagai respons dari latihan fisik, hanya menilai IGF-I dalam sirkulasi yang belum terikat pada sel target. ${ }^{15,16}$ Produksi IGF-I secara endokrin melalui perangsangan GH akan disesuaikan dengan kebutuhan anabolisme jaringan, sehingga nilai baseline dari IGF-I dalam sirkulasi akan dipertahankan dalam level tertentu, oleh karena kadar IGF-I dalam sirkulasi juga menyebabkan feedback negatif pada pelepasan $\mathrm{GH}$ melalui stimulasi pada hipotalamus untuk melepaskan somastatin dan secara langsung pada pituitari dengan memblok aksi GHRH. ${ }^{17}$

Pada kesempatan ini, penulis menyampaikan penghargaan, ucapan terima kasih, dan rasa hormat kepada Prof. Dr. dr. Wahyu Karhiwikarta, SpKO., AIF., Prof. Dr. dr. Ieva B. Akbar, AIF., dan Dr. Beltasar Tarigan, MS., atas segala bimbingan dan arahannya.

\section{Daftar Pustaka}

1. Nohonni T, Tobing AJ. Senam osteoporosis bagi orang sehat. Jakarta: FKUI/RSCM; 2000.

2. Kisner C, Colby LA. Therapeutic exercise foundation and technique. Philadelphia: F.A. Davis Company; 2002.

3. Hakkinen K, Sokka T. A randomized two years study of the effect of dynamic strength training on muscle strength disease activity, functional capacity and bone mineral density in early rheumatoid arthritis. Arthritis Rheum. 2000;44:515-22.

4. Maddalazzo GS, Snow CM. High intensity resis- tance training, effect on bone in older men and women. Calcif Tissue Int. 2000;66:399-40.

5. Benben RM, Fetters NL. Musculoskeletal respone to high and low intensity resistance training early postmenopausa women. Med Sci Sports Science. 2000;32:1949-57.

6. Taafe DR. Comparative effect of high and low intensity resistance training on thigh muscle strength, fiber area and tissue composition in elderly women. J Rehabil Res Dev. 2000;16:381-92.

7. Hakkinen K, Parakinen A. Basal concentration and acute respone of serum hormone and strength development during heavy resintance trainging in middle aged and eldery men and women. J GerontolA Biol Sci Med. 2000;55:95-105.

8. Adam GR, Exercise effecton muscle insulin signaling and action review: aotocrin/paracrine IGF-I and skeletal muscle adaptation. J Appl Physiol. 2002; 93:1159-60.

9. Kartinah NT. Respons akut dan kronik IGF-I setelah melakukan latihan fisik pada wanita lanjut usia. Medika Kartika. 2007;5:1-12.

10. Lanyon LE, Erlich PJ. Mechanical strain and bone cell function: a review. Osteoporosis Int. 2002;13: 688-700.

11. Jade WM. Role of nitric oxide and prostaglandins in the bone formation response to mechanical loading. Med Sci Sports Exerc. 2000;28:187-215.

12. Patel M, Arden L Masterson D, Phillips D. Investigating the role of the growth hormoneinsulin-like growth factor (GH-IGF) axis as a determinant of male bone mineral density (BMD). Bone. 2005;6:833-41.

13. Lange KH, Dall R, Christiansen JS, Lundberg PA, Baxter RC. The growth hormone/insulin like growth factor-1 axis hormone and bone markers in elite athletes in response to a maximum exercise test. J Clin Endocrin Metab. 2003; 88:1394-401.

14. Wideman L, Weltman JY, Hartman ML, Veldhuis JD, Weleman A. Growth hormone release during acute and chronic aerobic and resistance exercise: recent findings. Sports Med. 2002;32:987-1004.

15. Shoshana Y, Clifford JR, Wesley GB, Cheryl LA, Bicknell, Yipping W. Circulating level of IGf-1 direcly regulate bone growth and density. J Clin Invest. 2002;110:771-81.

16. Lavoie JM, Fillion Y, Couturier K, Corriveau P. Evidence that the decrease in liver glycogen is associated with the exercise-induced increase in IGFBP-1. J Appl Physiol. 2002:10;1152-9.

17. Laron Z. Insulin-like growth factor 1(IGF): a growth hormone. Mol Path. 2001;54:311-6. 